\title{
Sentidos do lado de fora: hipóteses sobre o pensamento social e o sentimento de incompletude brasileiro
}

\author{
Eduardo Brandão Pinto*
}

\begin{abstract}
Resumo: Partindo do ensaio de Roberto Schwarz, "As ideias fora do lugar" (1977), interpretado, por sua vez, sob instruções da "Dialética da malandragem" (1970), de Antonio Candido, busco uma leitura de duas obras que dissertaram a respeito da condição social brasileira dos momentos colonial e pós-colonial, Homens Livres na Ordem Escravocrata (1969), de Maria Sylvia Carvalho Franco, e Capitalismo e Escravidão no Brasil Meridional (1961), de Fernando Henrique Cardoso. A proposta fundamental é buscar afinidades entre as contradições notadas pelos autores na história brasileira e as tensões características do capitalismo moderno. Uma vez que na periferia desenvolveu-se uma forma de capitalismo lacunar e incompleto, isso só fez intensificar, desde os inícios de nossa história, o processo de individualização, propiciando uma experiência histórica muito distante daquela regularidade cosmológica que caracterizaria as formas tradicionais de vida. 0 paradoxo dado pelo par escravismo-exportação, que definiu durante a colonização a economia brasileira, cria tensões instauradoras de uma forma de vida que busca seus sentidos em meio às fragmentações e incompletudes do cotidiano.
\end{abstract}

Palavras-chave: periferia do capitalismo, pensamento social brasileiro, incompletude, história do Brasil, escravismo.

0 título deste artigo pode ser acusado, talvez muito corretamente, de usar recurso já revirado e desgastado na reflexão intelectual brasileira, a saber, a referência ao ensaio de Roberto Schwarz, "As idéias fora do lugar". O insight de Schwarz é aberto em uma consideração sobre aquilo que tem sido o tutano essencial da ideologia no capitalismo, a ciência: "Toda ciência tem princípios, de que deriva o seu sistema" (SCHWARZ, 2000a, p. 11). Logo no parágrafo seguinte, o autor associa a ciência ao espírito das Luzes, aceso no mesmo circuito em que ascendia a burguesia à pasta burocrática dos direitos políticos.

Havia um espectro, porém, dominando as relações de produção no Brasil do século XIX, botando-o fora - ou ao menos em posição periférica - do sistema da Ciência, de onde importávamos conceitos e os transformávamos, posteriormente, em categorias políticas e critérios éticos entranhados no imaginário social. Trata-se, como muito bem deve saber o leitor, do escravismo, um princípio social interferente no sistema de conceitos, provocando distúrbio entre sinais e sentidos. "Assim, com método, atribui-se independência à dependência, utilidade ao capricho, universalidade às exceções, mérito ao parentesco, igualdade ao privilégio etc." (idem, p. 19). Peço que o leitor retenha em especial um dos distúrbios citados por Schwarz, "universalidade às exceções", que se abre em duas dimensões, podendo ser lido como: 1. situação do Brasil, como país periférico e escravista, no contexto do capitalismo ocidental - isto é, a particularidade da estrutura social brasileira, ao mesmo tempo em que predomina-

Graduando em Cinema e Audiovisual - UFF. 
va a pretensão romântica de inseri-la dentro de um mapa universalizante, ressaltando no nacional as peculiaridades naturais (sempre pontuais) prontas a serem modeladas pela mão escultora do fino e civilizado homem da Europa; 2. exceção é também o homem livre e não proprietário, escamoteado da ordem do trabalho pela concorrência desleal com o braço escravo, que abastecia toda a demanda por mão de obra. Leia-se a citação de Sergio Buarque de Holanda, trazida por Schwarz nesse ensaio: "Trazendo de países distantes nossas formas de vida, nossas instituições e nossa visão de mundo e timbrando em manter tudo isso em ambiente muitas vezes desfavorável e hostil, somos uns desterrados em nossa terra'” (idem, p. 13). 0 Brasil, adotando a ordem internacional eurocêntrica como referencial de desenvolvimento, torna-se um outsider no mundo capitalista; igualmente, o homem livre é o estrangeiro desencontrado da sociedade escravocrata, em processo erradio de despratriarcalização, que oscila, malandro, entre as duas bases opostas do trapézio semi-estático da sociedade brasileira, num "balanceio caprichoso entre ordem e desordem" (CANDIDO, 1970, p. 76).

Mesmo apontando limitações no alcance da visão do autor de Memórias de um Sargento de Milícias, em seu ensaio citado de 1970, Antonio Candido constrói um painel da realidade brasileira exposta no romance de Manuel Antonio de Almeida. Realidade esta que serve como material intelectual e referência professoral ao ensaio de Roberto Schwarz. Leonardinho Filho, malandro de nascença, não pratica o delito por propósitos econômicos, como meio útil de vida, como instrumento racional de enriquecimento ou obtenção de renda; antes, é gosto gratuito e caprichoso pela subversão, que revela algo profundo em sua identidade cultural, é uma paixão lúdica e redundante à desordem sem fim, como valor e princípio que o carregam ao encontro da sociedade ao mesmo tempo em que o põem em conflito com ela. "Leonardo pratica a astúcia pela astúcia (mesmo quando ela tem por finalidade safá-lo de uma enrascada), manifestando um amor pelo jogo-em-si que o afasta do pragmatismo dos pícaros, cuja malandragem visa quase sempre ao proveito ou a um problema concreto, lesando frequentemente terceiros na sua solução" (idem, p. 69).

Leonardinho e os outros personagens oscilam entre a ordem e a desordem, não apenas como subversivos casuais, senão que a ordem produz o transgressor como forma de rearranjar o desarranjo gerado pela particularidade social em questão. A ordem, elemento universalmente integrador, torna-se excludente no contexto brasileiro, uma vez que a coexistência de escravo e homem livre usurpa deste último a essência de trabalhador assalariado, que lhe serviria de identidade e elemento socializante. A desordem surge como a forma particular brasileira da ordem, pois é ela que cumpre a função de transportar o excluído novamente para dentro da sociedade e das relações de produção. A subversão é o elemento fundamental que socializa o 
outsider, tornando regra a transgressão. 0 malandro é o brasileiro estranhado pela sua pátria, que reencontra seu espaço dentro do quadro social no papel nômade de transgressor ativo aqui, submisso conformado ali. Enquanto a ordem tem o escravismo como substância, o homem não escravo e destituído de posse fica alheio a ela, mas retorna ao colo da pátria pela via do comportamento subversivo. Trata-se de um movimento de exclusão/integração que percorre duas transformações: o homem livre é tornado estrangeiro pelo escravismo ao desfuncionalizar-se como não-trabalhador, em seguida é reinserido pela subversão obtendo sua nova identidade social.

Destarte, a polarização ordem/desordem torna-se não um conflito dialético progressivo, mas a expressão da ambiguidade dessas categorias; a ordem não cumpre sua função integradora sem lançar mão da desordem, de modo que a veiculação de um signo sugere tão-já o sentido do signo oposto: quando se diz "ordem" pensase imediatamente na desordem como um complemento necessário; cumpliciam-se num par, como se fossem duas palavras alinhadas na mesma bandeira - críticos do positivismo já disseram que "progresso" implica desordem, logo, a afirmação que fiz atrás pode ser lida em sentido literal, subvertendo nossa frase símbolo, de "ordem e progresso" para "ordem e desordem".

0 major Vidigal, que em princípio encabeçaria o eixo de ordem desenhado no romance, lança mão frequentemente - Antonio Candido elenca episódios do romance (idem, p. 75) - de meios ilícitos. A subversão como mecanismo socializador é não praticada somente pelo grupo dos potenciais malandros, que se serviriam da transgressão para a reinserção social; ela contagia verticalmente a sociedade brasileira urbana e extravasa o círculo dos homens livres sem propriedade, tornando-se fundamento estrutural. Tutto nel mondo è burla. A nova ordem admite a desordem, não apenas como desvario pontual e válvula de escape do rigor da regra, por onde a ansiedade humana manifestaria seu espírito juvenil e aventureiro; mas o lícito é já concebido prevendo sua insuficiência diante das ambiguidades da nossa condição periférica.

\section{Breve nota sobre o lado de fora 1}

A Lei como categoria dual, que não apenas aceita, mas que implica a transgressão tem sido reconhecida como forma cínica natural ao capitalismo recente entenda-se por recente o pós-II Guerra. Refiro-me sobretudo à interpretação de Vladimir Safatle em Cinismo e Falência da Crítica, que, embora engajado numa discussão com obras de referência distantes daquelas que orientam este ensaio, chega a citar "As idéias fora do lugar" de Schwarz e ensaiar suas pinceladas na tela da representação da formação histórica brasileira (SAFATLE, 2008, p. 78 e 79 e nota 19). 0 que 
nos interessa de sua notação é a extensão dos problemas da dualidade da Lei, como cumprimento e transgressão, às experiências normativas no capitalismo de centro. Entretanto, Safatle reconhece no capitalismo periférico condições sociais que otimizam a expressão da razão cínica como normatizadora da práxis e do discurso: " $a$ consciência 'metropolitana' sempre foi afetada pela existência de tais estruturas duais, mesmo que essa existência se revelasse de maneira mais clara em localidades geográficas distantes" (idem, p. 79). Nas experiências legitimadas de transgressão recorrentes na cultura européia pré-moderna - que Safatle identifica a partir da obra de Bakhtin (idem, p. 101-103) - o que ocorre é bem distinto: trata-se de ritos sociais em que a comicidade desempenha uma função subversiva, como uma crítica à norma que não a rejeita, mas que tem hora e espaço para acabar. São momentos e lugares circunscritos pela própria Lei, em que a transgressão é não somente permitida mas estatuída como norma, vestida no corpo e no gesto como fantasia risonha, livre para carnavalizar no salão até que se ouça o badalar da meia-noite e se retornem aos mesmos trajes recatados usados antes da celebração da festa. A norma instituída sob o regime da razão cínica, porém, distende a transgressão no tempo e no espaço, como experiências contínuas na nossa produção diária - no discurso, na arte, no trabalho, na afetividade, no sexo, na religiosidade, na política, etc. "O fato relevante aqui é como o que anteriormente estava restrito a momentos de anomia tende, na dinâmica ideológica do capitalismo contemporâneo, a colocar-se como modo hegemônico de funcionamento da Lei" (idem, p. 104). Se Brecht propusera a revelação dos valores ocultos através da ruptura com o ilusionismo burguês do drama moderno, sua mirada crítica certamente se dirigia contra a natureza de uma ideologia que, então, se fundava no ocultamento dos fetichismos das normas sociais. O "capitalismo cínico", para Safatle, como categoria característica da condição social, é pouco posterior.

Quer dizer que, ao menos no que toca à ambivalência dos critérios normativos, estaria o centro experimentando um capitalismo tardio, se comparado à formação histórica da periferia? E por que não pode ser brasileira a forma cínica do capitalismo contemporâneo?

A existência nos trópicos experimenta profunda sensação de insuficiência, já que aquilo que é concebido como normal à vida é imediata e reflexivamente desencadeador de movimento divergente, que nos lança fora, e em direções múltiplas, do quadro onde se sistematizam os valores e os critérios éticos e políticos. 0 esquema social dominante não é apenas contrariado em situações de exceção, mas toma sua essência na forma da incompletude solicitadora de algo mais, ela própria instauradora de seus contrários. 0 indivíduo - seguramente individualizado, longe daquela regularidade cognitiva que caracterizaria a pessoa - operacionaliza sua inserção na to- 
talidade social, lançando-se no jogo das tensões de significados e signos destoantes, inventando sua identidade sob as lacunas de uma ordem ambígua e insegura. E pra se equilibrar no meio do bamboleio violento de ordem e desordem é preciso ginga!

Os menores detalhes da vida cotidiana carregavam-se de tensão humana, uma vez que a incompletude das determinações sociais não prescreviam um repertório de soluções possíveis para situações de crise, de modo que só pelos rumos da interação, de homem para homem, definiam-se os comportamentos concretos. A obra Homens Livres na Ordem Escravocrata, publicada originalmente em 1969, de Maria Sylvia Carvalho Franco, em diálogo com a qual é escrito e lido o ensaio de Roberto Schwarz, "As idéias fora do lugar", atribui valor às brigas e conflitos físicos dentro de comunidades, descritos no livro a partir de registros judiciais e policiais. Esses embates, tradicional e universalmente experimentados como dispositivos reinstauradores de um estado de ordem ameaçado ou perdido, criam, no contexto das relações entre vizinhos no Brasil do século XIX, situações em que se pode ver privilegiadamente a frouxidão das determinações sociais na composição de um suposto protocolo de ação a ser seguido pela pessoa.

Mesmo quando pessoas estranhas se medem numa situação que seria de molde a predispor para um ajuste tempestuoso, as soluções drásticas não surgem como resultado necessário das circunstâncias que fundamentalmente as provocaram. É, antes, no interior do próprio conjunto imediato de relações, ao longo da concretização das condutas, à medida que vai nelas sendo impressa a figura de seus autores, que as tensões se agravam progressivamente até culminarem em luta (FrAnCo, 1974, p. 23).

É preciso particularizar o sentido da comunidade na experiência histórica brasileira. Max Weber reconheceu à comunidade de vizinhança a importância do "trabalho de favor", bem distinto, porém, do favor brasileiro, do homem livre, que toma a forma às vezes da pura bajulação. A comunidade weberiana é baseada em laços fraternais, de onde desponta o favor como manifestação de um sentimento de identidade: são solidários porque dividem a mesma rua e se aliançam num mesmo sistema de tradições (WEBER, 1999). 0 favor à brasileira, por sua vez, é interestamental, e ainda mais do que isso: atravessa não só de alto a baixo da pirâmide, quebrando o princípio do favor como expressão do sentimento de solidariedade, como, também, busca seus pares no lado de fora da ordem e alcança essencialmente os indivíduos que estão marginalizados pelo esquema bípede e deficiente de senhor/escravo; isto é, o favor é praticado largamente por homens livres e sem posse que tentam atrair as estimas dos proprietários, dois sujeitos sociais distanciados pelas suas condições econômicas e humanas, mas reaproximados numa interação lúdica, proveniente de uma poesia malandra das formas sociais.

Trazemos, assim, na totalidade social o favor, que, segundo a lógica do capita- 
lismo de centro, seria um rasgo localizado e passageiro. A sociedade brasileira imanta em sua estrutura o comunal banco de calçada, signo da sociabilidade fraternal de bairro, mas lhe dá significado e função particulares: em vez de servir como ponto de encontro entre vizinhos que socializam sem compromisso após o expediente de trabalho e assim pelo diálogo e pela proximidade consolidam um sentimento de comunhão coletiva, transforma-se na arena onde a moça de pais livres e sem posse cruza as pernas em saiote justo, a fim de atrair a atenção do moço rico que, quiçá, lhe bancará a vida; em vez do convívio baseado na partilha de identidade - moram próximos, o que quer dizer que certamente vivenciam problemas e condições de trabalho semelhantes, tornados força de atração -, o banco de calçada é o palco do jogo integrador oscilando entre ordem e desordem, em que por meio da sensualização e das formas particulares dos conflitos cotidianos rompem-se os limites da ordem, abrindo as relações entre os indivíduos para uma totalidade mais abrangente.

Por ocasião da referência à luta entre um Dionísio e um Amaro de tal, comenta Maria Sylvia: "Nota-se aí como a disputa é encarada como um assunto privado, cabendo aos adversários decidi-lo como melhor lhes aprouver" (idem, p. 52). Compare-se com o tradicional duelo europeu, em que uma lista de protocolos ritualiza o embate entre dois homens que procuram solucionar alguma desavença. A subversão às normas que rigorosamente regem o duelo implica tão profunda desonra ao transgressor que seria preferível ser abatido sem trapacear do que vencer e manter-se vivo trapaceando. Nada tem a ver com os relatos de brigas transcritos por Maria Sylvia nesse "Cap. 1.0 código do sertão". A violência no duelo europeu implica a injeção de um sistema subordinado à ordem dentro da irrupção da desordem, de modo que o conflito entre os pretendentes à mão da virgem recupere os critérios que regem a vida na instância da ordem; assim, o duelo fica sendo o instante em que os princípios da regra são levados à última consequência, estando a regra literalmente acima da vida - a conservação da norma convencionalizada é preferível à manutenção da própria vida do duelista; o sistema de regras impiedosamente respeitado pelos homens em embate reinsere-os no estado de ordem, progredindo para a solução absoluta, isto é, a eliminação de uma das partes, resultado que garante definitivamente a restauração da ordem ameaçada pela competição entre os homens - e assim escolhe-se o desvirginador da moça pretendida, em critérios críveis, já que determinados pelo princípio da ordem, em que o vencedor é produto do mérito da aptidão física e da habilidade no manejo das armas. Do lado de cá na periferia, a luta é experimentada pelo brasileiro como divergência de intenções, na anomia das próprias formas sob as quais a violência se dá. Não há regra prévia que respeitar na hora da briga, senão aquelas que podem ser ludicamente pactuadas pelos lutadores no instante do emba- 
te, e não se bate no outro com fins de restauração e descoberta definitiva de solução para o problema causador do confronto. A luta não só não cumpre papel de restituição coercitiva das normas sociais, como - é possível dizer - expressa mimeticamente a totalidade social brasileira na forma das facadas e outros golpes corporais. Os trechos de autos de crimes citados pela autora deixam ver o descaso em circunscrever critérios básicos de toda luta minimamente normatizada ou equânime, como a paridade de condições de defesa e ataque entre os que lutam, ou como a prescrição dos meios pelos quais a violência poderia ser exercida - muito ao contrário, novamente, do duelo europeu em que se preza, em primeira importância, pela absoluta eliminação de qualquer desvantagem entre os duelistas, de modo ao resultado representar inefável mérito ao vencedor e resignação ao atingido. 0 agressor, na luta brasileira, pode abrir mão, entretanto, do meio de ataque de que lança mão, caso sua utilização gere suspeita sobre as qualidades do lutador, suspeita que pode manifestar-se ou não, dependendo dos rumos das interações entre o agressor e o agredido, e não definidos por critérios culturais fixos - como é o caso do agressor que se desarmou de uma espingarda e decidiu atirar-se como as mãos sobre a vítima, ao sofrer desta última uma gozação em que era questionada sua hombridade diante do uso de tal ferramenta de ataque.

Um dos tipos sociais de homem livre tomado como personagem da obra de Maria Sylvia é o vendeiro, cuja posição no quadro de relações econômicas acha-se no meio de um entroncamento chave, do alto do qual boa parte do cenário das contradições brasileiras pode ser vista. Se a dependência da produção econômica ao importador estrangeiro do produto primário colhido em excedente nas grandes fazendas configurava um caráter mercantil à economia nacional, no interior do país, por sua vez, dominava a produção de subsistência ou voltada para o consumo local imediato. 0 vendeiro é aquele responsável pelos grandes armazéns, distantes dos principais centros urbanos, de modo a operar um intermédio entre as populações afastadas, muitas vezes de grandes famílias patriarcais, e a oferta de bens de consumo, encontrada nas cidades. Assim, o dono da venda procura seu sórdido lucro em meio a uma estrutura social ainda familiar; põe em contato os campesinos ao redor do fazendeiro com a oferta de bens de consumo, cuja forma elementar vem lá de longe, do centro do capitalismo. Entretanto, nem o dinheiro havia em montante suficiente para permitir ao vendeiro uma vida de lucros, tal qual um capitalista de origem, nem a força do dinheiro como meio universal de troca e medida dos valores estava socialmente assentada a ponto de monetarizar as relações entre homens e entre homens e coisas; essas lacunas que as deficiências da função-dinheiro - seja como entidade física existente em pouca quantidade, seja como estruturador cognitivo deficiente 
dos indivíduos que, assim, não se tornavam perfeitos sujeitos monetários - eram preenchidas por outros requisitos individuais, como a esperteza, a bajulação, a sedução: "a astúcia e a malícia para criar e exaurir as oportunidades de formar pecúlio num meio em que o dinheiro era escasso" (idem, p. 77)².

Chegamos aqui a um ponto de tensão fundamental na sociedade brasileira: a forma especial como o dinheiro, e consequentemente toda a noção individual de valor e o raciocínio monetário, é significado numa estrutura em que convive o trabalho escravo com a produção para a exportação, para a qual estavam orientadas as grandes fazendas brasileiras já na plenitude do período colonial, nos séculos XVII e XVIII. Os latifúndios no Brasil colônia estavam submetidos a uma exigência demarcada pela força dos acordos coloniais e imposta pela metrópole: produzir excedente a ser comprado, a baixo preço, pelos importadores portugueses, interessados no produto primário tropical. Os senhores das fazendas brasileiras, por sua vez, vendiam o excedente para os mercadores vindos de Portugal, o que lhes rendia um pequeno mas persistente lucro. Embora o lucro proveniente da venda do excedente circulasse dentro da colônia, não se configuravam bases amplas para a oferta de bens de consumo capaz de absorver todo o dinheiro recebido pelos exportadores. Em síntese, os proprietários brasileiros constituíam potencialmente o rascunho de um mercado consumidor, sem que, no entanto, vissem ao seu alcance para onde destinar esse dinheiro, que, assim, vagava de mão em mão, sem poder de compra, já que pouco havia para comprar. E uso o advérbio "potencialmente" a fim de expressar um poder contido, porém não manifesto; se por um lado, a camada senhorial estava, em termos de montante econômico em reserva, preparada para o consumo, por outro, a inexistência de uma estrutura ofertante não permitia que o dinheiro se carregasse com as funções que dão a ele significado, segundo aprendemos com a Economia Política.

Na experiência do sujeito monetário capitalista, a vigência do dinheiro como intermediador das relações econômicas entre os indivíduos está justificada pela importância recíproca e impessoal que o dinheiro garante: tendo-o sob sua posse, ele dá acesso a um sem-número de bens, serviços e honrarias, não importa quem o possua; o indivíduo que sacrifica o prazer para empenhar-se em horas de traba-

\footnotetext{
2 Semelhante à posição especialmente dialética do vendeiro é a do comissário, que emprestava dinheiro ao fazendeiro, sem que, no entanto, contasse com a garantia do lucro, fruto dos excedentes da fazenda, que futuramente lhe pagariam o crédito. "A figura do comissário, atrás delineada, constitui o elo de ligação entre os mercados mundiais e o produtor de café, intermediário que, de um lado, reuniu os recursos vindos do exterior e controlou a sua distribuição e que, de outro, organizou a comercialização do café nos moldes requeridos pela exportação. Aglutinando em torno de si os capitais estrangeiros e os gêneros nacionais, ele como que personificou, nas condições brasileiras, o nexo entre os países 'coloniais' americanos e a expansão do capitalismo. A rigor, a economia do café não escapa ao esquema geral que relaciona esses países ao desenvolvimento do sistema central" (idem, p. 172; sobre o comissário, ver ainda: p. 158-172).
} 
lho será futuramente recompensado no momento do consumo, quando o sacrifício e o trabalho alheios serão colocados, agora, em favor do seu gozo. 0 dinheiro, desse modo, desempenha função como articulador de um sistema cosmicamente completo e lógico, em que representa um ponto de passagem para a obtenção de algo que se quer possuir, é gestor e regulador da economia de prazer.

O dinheiro em estado de vacância, como o experimentavam os viventes brasileiros do período colonial, fica destituído do seu poder agregador e integrador, como meio de acesso que interliga as pessoas umas às outras, dá lógica às hierarquias e aos ramos de trabalho e atua como instaurador de um novo significado à vida. (E faço essa conceitualização negativa - buscando compreender o dinheiro na história brasileira pelo que ele não é ou não significa - justamente na ansiedade de mimetizar essa identidade formada a partir do que falta, do ausente, do castrado.) A peça de dinheiro torna-se signo morto, mas eternamente quente: desencarna-se do sopro de vida que mantinha dentro dela a sua alma, garantindo, assim, a existência de algo mais do que a materialidade cotidiana, que transportaria o indivíduo monetário para um universo em que suas expectativas racionais e emocionais seriam retribuídas e ganhariam sentido humano; entretanto, preserva sua capacidade de atrair os interesses individuais, já que é símbolo, remoto e distante, de poder e posição hierárquica. 0 dinheiro, ao ter enfraquecida sua função de meio universal de troca, deixa de ser a expressão de um valor e de um trabalho morto, é o fim em si, redundante e lúdico; é o sol que não se punha no império do escravismo periférico.

\section{Breve nota sobre o lado de fora 2}

A funcionalização (ou desfuncionalização) do dinheiro serve de critério para Roberto Schwarz notar o "pulo do gato" em que se lançou Machado de Assis, transpondo muros antes respeitados pelo romance urbano brasileiro, em especial pelo Senhora de José de Alencar (SchWARz, 2000b). Lá fora, de onde escreve Balzac, referência do romance alencarino, se, por um lado, o dinheiro cumpre seu papel como mediador das relações entre pessoas e coisas ou pessoas e pessoas, por outro, a intensificação do poder de troca e de consumo do dinheiro leva a outras contradições. Uma vez estabelecido como meio universal de troca, a intrusão do dinheiro nas relações humanas não fica livre de estetizações: como mediador-mor da vida na cidade, o dinheiro estiliza-se e reivindica sua alforria frente à funcionalidade restrita que antes lhe cabia, torna-se dono de si mesmo, instaurador de formas de vida e alvo de toda a atenção humana. 0 avarento Rastignac, personagem que circula entre as vielas escombrosas descritas por Balzac, mede em dinheiro não somente o valor das coisas, mas o esforço que despende com os colegas de faculdade e as meninas que corteja, assim como o pai Goriot atesta 
sua submissão às filhas deixando-as falirem-no.

Longe de entender a avareza como má índole do gênio humano das personagens encantadas com o poder do níquel e dispostas a tudo, é na própria significação do dinheiro como instrumento social que a contradição deve ser encontrada. De mediador na relação de permuta entre duas mercadorias, que Marx representou pelo esquema M - D - M, o dinheiro alça-se como finalidade do empenho humano e motivador das forças subjetivas, convertendo o circuito anterior à forma transtornada D - M - D. De significante do valor das coisas, o dinheiro passa a valor-em-si; ao invés de obedecer à sua função de escala comparativa para o valor-de-troca das mercadorias e das pessoas, acontece o inverso: como numa bruxaria, as pessoas e as coisas são transfiguradas em signos que expressam o valor do dinheiro.

Em ensaio de 1890, "Psicologia do dinheiro", decorrente de aula ministrada um ano antes, sobre o movimento que transforma o dinheiro de meio em fim, recentemente publicado em português, Georg Simmel comenta:

Se no tráfico monetário uma pessoa tem exatamente o mesmo valor que outra deve-se exclusivamente ao facto de nenhuma das duas, mas tão-só o dinheiro, tem valor. Por isso, é de todo correcto afirmar que, em questões monetárias, cessa a amabilidade: o dinheiro é o objetivo absoluto, em que todo elemento pessoal acaba (SIMMEL, 2009, p. 34).

O dinheiro capitalista é inodoro, porque suas peças são mantidas intactas e alheias à mundaneidade ao redor que tudo rói e consome, uma vez que as peças de moedas e notas buscam tão-só sua reprodução, pervertendo o movimento natural que corre rumo à morte e ao fim. É indiferente, pois o objeto comprado é vão, interessando antes o gesto da compra. É anti-histórico, pois descreve uma narrativa cujo ponto final é essencialmente idêntico ao ponto de partida: a posse do dinheiro, variando apenas sua quantidade.

Roberto Schwarz identifica os personagens centrais do romance Senhora, publicado em 1875, como habitantes de um mundo em que o dinheiro tomou posse das relações humanas, dos critérios da escolha no amor e nos afetos, tal como descrito nos parágrafos anteriores. Restaram aos personagens periféricos, porém, à distância desse mundo monetarizado, a eleição de outros sensos na costura da vida afetiva, tendo o favor como principal mediador das relações hierárquicas (ScHWARZ, 2000b, p. 50). Caberia a Machado de Assis a sacada de que, ali, a periferia sobressaía ao centro, e fazer desses personagens descapitalizados o tutano de suas narrativas, mais afins à realidade social brasileira, enquanto os protagonistas de Alencar se prestavam mais à realidade monetarizada de uma Europa.

Esclareçamos o passo galgado nesta "Breve nota": aceitamos que a escassez 
de objetos de consumo no Brasil colonial fissurava o fluxo lógico do processo de troca mediada pelo dinheiro, donde emerge a contradição que o fetichiza enquanto expressão do poder social de quem o possui; entretanto, ao indicar a origem desta contradição, instaurada que está na singularidade da condição periférica brasileira, que perversamente alia escravidão à produção para a exportação, corremos o risco de sugerir que qualquer contradição da função dinheiro no capitalismo estaria restrita à periferia; embora não seja empreitada deste artigo discutir a perversidade capitalista nos países de centro, com os exemplos de Balzac e Simmel alçamos a conclusão de que um processo combinado de contradição gira suas engrenagens mesmo onde não falta o que consumir, como na Paris oitocentista e na Berlim que cruza do século XIX ao XX.

Diante dessa desigualdade combinada entre lá e cá, resta-me a suspeita: não seria a condição periférica um painel privilegiado no entendimento da contradição capitalista, uma vez que parece trazer já na terra a larva que depois pousaria cinzenta na Europa oitocentista? Somos periferia do capitalismo, mas centro da contradição? Talvez, então, valesse inverter o fluxo originário que nos informa os conceitos sociológicos, pois quem chega tarde ao banquete do fetichismo não foram senão os personagens de Balzac?

As fazendas na América do Norte, submetidas a um controle metropolitano muito mais frouxo e menos sistemático do que aquele que cá mantinham os portugueses e intensificando a troca de mercadorias entre si, rapidamente se transformaram em empresas que visavam potencializar a produtividade, o que implicava pontuais inclusões do escravo no sistema de benefícios. As colônias do Norte instituíram a participação de negros nos lucros; a compra da alforria funcionava como um privilégio obtido pelos escravos que, por meio do trabalho e da capacidade em calcular custos e inflar seus ganhos, conquistavam a alforria e a participação na vida de consumo e produção - como trabalhador livre ou mesmo proprietário (WILLIAMS, 1944). No Brasil, por outro lado, o sacrifício do trabalho não formava para o escravo qualquer sentido mais profundo do que o imediato cumprimento de um mando, imposto à base da força. Nem a perspectiva do benefício futuro, nem a adoração tradicionalista ao amo motivavam o negro a trabalhar e a viver com algum entusiasmo seu estado atual de cativo. Apenas a quebra da ordem seria o único caminho, instável e incerto, de significar a existência do homem negro. A fuga ou a busca pela simpatia do senhor eram as formas com que a condição de escravo era superada, no caso da fuga, ou brevemente relativizada, no caso do estreitamento de intimidades com os brancos proprietários. Sobre a fuga, Fernando Henrique Cardoso escreveu: 
impostas a esperança de liberdade. Por esse motivo, não era movido, em tese, por qualquer incentivo suficientemente forte por si mesmo para mantê-lo na conformidade com as regras impostas. Ao contrário, só pela negação total da situação em que se via envolvido, através da fuga, poderia encontrar a liberdade (CARDoso, 2003, p. 173-174).

Os mercadores portugueses desenvolveram um conhecido sistema para que o lucro dos fazendeiros brasileiros retornasse às suas mãos, um canal por onde o dinheiro excedente na colônia fosse todo escoado pelo Atlântico de volta a Portugal e que, assim, justificasse o emprego da mão de obra escrava na colônia como forma de gerar pecúnia em benefício da metrópole. Havia um único bem de consumo que os proprietários brasileiros tinham ao alcance para exercer o ato da compra como legítimos consumidores e assim darem rumo ao dinheiro excedente que lhes mofava nas mãos: os negros, vindos da África e traficados pelos mercadores portugueses. Era na compra do escravo que o dinheiro aportado no Brasil pelas exportações tornava-se um meio de troca capaz de dar ao indivíduo-fazendeiro acesso a um bem útil e valorizado; no comércio negreiro o dinheiro efetivamente carregava-se dos significados capitalistas que a ele atribuiu a Economia Política, como representante quantitativo de poder de compra, instância numérica em que se calcula o montante de uma riqueza.

Para efeito de mercado interno brasileiro, constitui-se um processo circular: a escravidão é a reprodução, a garantia e o sustento da própria escravidão; negros eram geradores de uma riqueza empregada na compra de outros negros; mais-escravos. Assim, redundantemente, o escravo representava, para o proprietário, um meio para a aquisição de mais escravos, enquanto, para o escravo, ele trabalhava a fim de esvaziar as choupanas africanas e trazer novos conterrâneos seus para as fazendas brasileiras. Senhor e escravo empenhavam-se duro na manutenção de um sistema fechado e duplamente transtornado pela neurose capitalista: não bastasse o dinheiro transformar-se num fim morto e sem continuidade, como único representante pervertido dos significados a que ele não conduz, o escravo passa a ser a nova forma representante do dinheiro, o signo por excelência da experiência histórica brasileira. Nesse sentido, o escravo não era exatamente uma coisa, conforme tanto insiste a nossa historiografia, mas coisa-em-si, deslocada do mundo das outras coisas, um totem quantitativo que expressava a riqueza de quem o tivesse. "À característica fundamental da produção capitalista de 'produção pela produção', imposta pela dinâmica da acumulação do capital, substitui-se no regime escravocrata a 'produção pela escravidão', ou a 'produção da escravidão' como uma norma duplamente irracional” (idem, p. 220).

0 autor refere-se ao escravo como "instrumento", mas cuja única "instrução" seria a de objetivar a posse: "O escravo transformava-se num instrumento cuja pre- 
sença era sentida e desejada na medida em que significava a objetivação de um valor fundamental dessa sociedade: a posse do instrumento de trabalho, a materialização da fortuna" (idem, p. 178). 0 escravo era signo que traduzia, antes de mais nada, o poderio econômico do proprietário. Um signo-fetiche, frente ao qual o uso prático e utilitário sobrava para segunda importância; a posse servia, primeiramente, à pura manifestação da posse em si, e o caráter de posse devia ser reafirmado pelo arbítrio do senhor sobre o escravo, o direito de fazer com ele o que quisesse. Tanto é, que a violência que marca a relação branco-negro no escravismo brasileiro não é aquela definida pelo castigo corretivo, com o fim claro de manter o negro quieto e empenhado no trabalho, mas, sim, é a crueldade dos melindres dos senhores e das senhoras que fustigavam o negro ao sabor dos caprichos seus, sem maiores propósitos além da satisfação desse prazer sádico que reificava sua condição de proprietário e superior, de modo que a ideia de castigo funcionava antes como justificativa moral do que como motivação e regulador dessa violência.

Na sociedade escravocrata brasileira não houve tendência a se prescreverem situações para as quais a violência física seria a solução necessária; houve, sim, um único fato essencial e profundamente violento, o da submissão de um ser humano ao gosto e à vontade gratuita de outro, vontade esta que, na falta de fins práticos e racionais, descambava frequentemente em atos ricos em malvadeza, em que o senhor via no escravo, e mais frequentemente na escrava, uma possibilidade de dar lastro às suas mais impensáveis fantasias sexuais e de sadismo humano.

Falta aos senhores um suporte lógico que dê norteamento à administração da fazenda e à exploração do trabalho escravo, o que na lógica capitalista é cumprido pelo ideal da produtividade e da elevação da taxa de mais-valia relativa. Fernando Henrique e Roberto Schwarz circundam este mesmo problema, de modo que o segundo o sintetiza fazendo referência ao primeiro:

Comentando o que vira numa fazenda [brasileira], um viajante escreve: 'não há especialização do trabalho, porque se procura economizar a mãode-obra'. Ao citar a passagem F. H. Cardoso observa que 'economia' não se destina aqui, pelo contexto, a fazer o trabalho num mínimo de tempo, mas num máximo. É preciso espichá-lo, a fim de encher e disciplinar o dia do escravo (SchWARZ, 2000, p. 14).

A vida no Brasil colonial é sentida tanto pelo senhor como pelo escravo a partir dos estímulos da ausência ${ }^{3}$, a falta de um princípio que arremate as relações

\footnotetext{
3 Embora esse sentimento de falta coexista no senhor e no escravo, vale notar que a atenção de Fernando Henrique concentra-se especialmente nas consequências dessa ausência para a condição do senhor. É ele o protagonista de Capitalismo e Escravidão no Brasil Meridional. A violência é entendida pelo autor como decorrência, antes de mais nada, da supressão de uma racionalidade gestora - que poderia ser inclusive a razão produtora da mais-valia relativa. Desse modo, a fissura que violenta a sociedade brasileira está no alto de nosso "trapézio". Se alguma potência transformadora havia, embora nunca manifesta, ela seria sem dúvida encontrada na camada
} 
econômicas e integre as expectativas humanas em alguma cosmologia completa e satisfatória; há algo a fazer a fim de preencher um espaço deixado vazio pela perversão controversa do modo de produção. A incompletude é o sentimento ambíguo de não ter algo essencial ou não ser parte do todo ao mesmo tempo em que é a consciência do poder ter algo mais ou ser em si mesmo o todo. 0 sentimento de falta é par, antagônico e coexistente, da consciência de possibilidades, a percepção de que o ser não está necessariamente atrelado ao curso histórico já previamente conhecido, de que está fora de um suposto sistema coordenador que lhe reserva um papel coadjuvante e subordinado na lógica global.

Fernando Henrique cita um código criminal que definia limites para a violência com a qual podiam ser fustigados os escravos, interpretando-o como demonstração de um reconhecimento parcial da humanidade do escravo (2003, p. 194 e 195 e nota 45 referente à p. 180). 0 que fica claro, porém, é que a restrição legal visava a conservar o escravo, preservá-lo da morte, o que seria economicamente negativo; partindo disso, é dedutivo que a violência exercida sobre ele pelos senhores não empregava métodos racionais com relação a fins, já que não raro invalidavam o negro para o trabalho ou até mesmo matavam-no; a violência ao negro resultava muitas vezes num atentado ao lucro do próprio branco proprietário que o violentou. 0 castigo não cumpria papel na engrenagem do lucro, ao contrário, muitas vezes era prática prejudicial à produção de excedentes na fazenda. As fustigações morais, físicas e sexuais ao escravo eram artifício para deixar claro quem mandava e quem obedecia. E na economia de prazeres, o desejo de mandar preenchia um espaço deixado vazio pela descontinuidade do fluxo produtivo, entre produção e consumo. 0 ato da crueldade provinha da euforia de se saber dono de outro ser humano, podendo subjugá-lo sob seu total arbítrio, livre até da necessidade de fazer com ele um bom uso de acordo com alguma orientação prática. Nesta linha, podemos inclusive compreender as conotações que atualmente dão sentido polissêmico à palavra "escravo", expressão abundante na vida sexual moderna brasileira (e certamente não só), ouvida e sussurrada dos clubes de sadomasoquismo à cama de motel, em que lançamos mão de tal termo - com suas variantes e seus diminutivos adocicadores, "servo", "empregadinha", "escravinha", "escravinho" - como o prazeroso insulto que durante o ato sexual teatraliza uma relação de posse e dominação de um dos amantes sobre o outro. A palavra "escravo", finalmente, supõe uma ambiguidade, tanto no uso presente (teatralizador), como no passado (efetivo): dirige-se a um ser paradoxalmente caracterizado como coisa e pessoa ao mesmo tempo; melhor dizendo, é uma pessoa

senhoril. Maria Sylvia, por sua vez, percebe a contradição existente nas camadas populares: o trabalho escravo excluía do sistema da ordem o homem livre e sem posse; note que, aqui, a condição do proprietário é secundária, de modo que toda transformação possível só poderia acontecer de baixo para cima. 
que, ao ser rebaixada a uma condição análoga à de uma coisa, encontra uma nova essência humana, sintética e controversa. Se nos aproximarmos um pouco, por mais terrível que este exercício possa parecer, da lógica de um sádico, é fácil constatar que não tem "graça" subjugar aquilo que já é, por alguma definição anterior e natural, completamente subjugado a ponto de anular-se como ser; não existe sadismo sem sentimento de alteridade ${ }^{4}$.

Donde, a interação sexualizada e violenta entre o senhor e o escravo sintetiza o paradoxo fundamental da sociedade escravista brasileira, que consiste em fazer de um ser humano signo a ser disputado como totem de poder, entretanto desprovido de sentidos completos que lhe prescrevam um destino exato.

As relações sexuais entre senhores e escravas, apesar do caráter de pura concupiscência, desencadeavam processos de interação social que escapavam inteiramente do jogo de expectativas sociais que definiam o comportamento de senhores e escravos (idem, p. 310).

Isso evidencia, amplamente, as inconsistências do sistema de castas brasileiro que, ao mesmo tempo que se criou para garantir a reificação do escravo, requerida pela produção econômica escravista, não se organizou a partir de valores culturais capazes de negar toda e qualquer qualidade humana do escravo. A literatura da segunda metade do século [XIX] é rica de textos que mostram, exatamente, o oposto: há como que uma redescoberta do homem no escravo. A ênfase posta pelos textos no carinho das mucamas, na fidelidade dos negros velhos, no sofrimento da mãe-escrava, na dedicação e amor pelo senhor etc., possui uma ambiguidade que é significativa. Exaltando as qualidades de apego ou de submissão aos brancos, textos deste tipo como que preparam a imagem do negro livre desejada pelos senhores, mas, ao mesmo tempo, obrigam a uma revisão da representação social do negro, descobrindo no escravo a pessoa humana (idem, p. 311$)^{5}$.

\footnotetext{
4 Afirmação que pode ser defendida e construída inclusive em sentido psicanalítico. Vladimir Saflate interpreta o fetichismo como o desejo pela transformação do outro em objeto de desejo, e não simplesmente no desejo pelo outro na forma acabada de objeto de desejo. Isto é, o fetichista é apaixonado pelo processo transformador, pelo ato dinâmico da objetificação, de modo que a consideração do outro como sujeito é um ponto de partida obrigatório, sem o qual ter-se-ia somente um objeto, e não um sujeito objetificado. "O sádico goza desse processo temporal, desse movimento de passagem do sujeito no objeto, e não apenas do outro totalmente reduzido à condição de objeto. Essa distinção é importante por nos lembrar como a perversão é uma espécie de intersubjetividade posta que é, ao mesmo tempo, intersubjetividade negada. (...) Nesse sentido, não é totalmente correto dizer que o perverso exclui o reconhecimento do desejo do outro. $O$ que nos abre à questão de saber qual seria então o fundamento de uma crítica psicanalítica à perversão" (SAFATLE, 2010, p. 80).

5 Ainda Vladimir Safatle, nosso interlocutor na crítica de viés psicanalítico. Em Cinismo e falência da crítica o autor analisa esse "redescobrir da pessoa humana no escravo". "Nessa chave interpretativa, o que é humilhado no masoquismo pela figura feminina é aquilo que, no sujeito, moldou-se à semelhança da identificação paterna, é aquilo que, no sujeito, assemelha-se à imagem desse pai em 'crise de investidura'. Ou seja, ao invés da repressão do supereu paterno como resultado da internalização da identificação paterna, teríamos, no masoquismo, a sua destruição. Ao insistir na recorrência do tema 'você não é um homem, eu transformo você em um' que sai da boca das dominadoras dos romances de Sacher-Masoch, Deleuze lembra que 'ser um homem', aqui, 'não significa em absoluto fazer como o pai, nem ocupar o seu lugar. É, ao contrário, suprimir seu lugar e a semelhança com ele a fim de permitir o nascimento de um novo homem" (SAFATLE, 2008, p. 163). Entretanto, o escravo de que falam Deleuze e Safatle é uma figura parodística, cuja situação é sem dúvida distinta da bárbara condição dos escravos por imposição da Lei social, de que falamos ao longo do ensaio e que é objeto do argumento de Fernando Henrique. Um é tornado escravo na experiência lúdica de um teatro pactuado, com espaço e tempo circunscritos, outro é
} 
O espetáculo da submissão é o sol que nunca se pôs nas redondezas do capitalismo periférico. A interação senhor-escravo, dentro da qual a violência espúria funcionava como realizador subjetivo dos indivíduos, sendo ela mesma a esfera essencial onde se desenvolve e significa a relação econômica entre esses sujeitos, é capaz de dar ao escravo uma parcial consciência - senão de classe - de si, como indivíduo e subjetividade ativa que, embora em desfavorecimento, seja chamado a participar do jogo de sedução e violência, que distribui o casting entre os atores sociais, dando ao escravo o papel de propriedade e ao senhor o papel de proprietário. Desse modo, ao passarem por experimentações sexuais e físicas, vividas como reguladoras de sua condição de classe, os escravos tocavam, no cotidiano dessas experiências, a totalidade social em seu cerne, experimentavam a vida nos trópicos justamente naquele ponto para onde toda ela convergia e formava sentido. As relações de sexualidade, por mais imbuídas de violência que estivessem, reafirmavam concretamente dia a dia o jogo de papéis que a economia fixava, cultivando, assim, a germinação de experiências conscientes e conscientizadoras; era entre a cama da mucama e o matagal atrás da senzala que as condições humanas de cada sujeito em interação eram percebidas como desenvolturas de uma totalidade social que impunha à força a inferiorização do negro (sobre a consciência de classe do escravo: idem, p. 168-170).

A expressão da condição social do escravo por meio da submissão à sexualidade inclinada à violência e desenrolada num espaço individualizado dificulta, porém, a formação de uma consciência política. No Brasil escravista, a noção de coletividade é atingida somente por meio da experimentação de situações concretas e cotidianas, ligadas à instância do indivíduo, dentro das quais o outro é concebido como par no jogo de sedução ou na violência imposta. A consciência de grupo, como abstração e destino comum, parece faltar ao negro e ao branco. A totalidade social a que o escravo e o senhor têm acesso perceptivo pela via da interação libidinosa e hostil exclui a operação cognitiva que compõe um tecido social a partir da abstração das solidariedades humanas. (Como já foi dito atrás sobre a ordem que, no contexto brasileiro, implica e invoca a desordem, de modo análogo a totalidade contém a essência da falta e, assim, não supõe completude.) Qualquer forma de ação mais diretamente relacionada à totalidade de classe, como coletivo abstrato - isto é, refiro-me à ação efetivamente política, em que os grupos se coordenam formal e explicitamente na defesa de interesses próprios -, fica escamoteada da ordem daquilo que dá sentido à vida. Não se forma, assim, a noção individual de esfera pública, a dividir interesses e compromissos humanos com a esfera privada. Quando um ser humano

escravo involuntário, cuja submissão é imposta através de coação, de forma ininterrupta, que incide sobre todas as instâncias da vida e modela todas as relações intersubjetivas experimentadas pelo indivíduo escravizado. Apesar das diferenças, qual não é a potência da paródia e do teatro em lançar luz sobre a vida concreta para esclarecer os paroxismos da violência social? 
se torna propriedade de outro, isto é, um homem e uma mulher são alçados ao caráter de instância privada, todo o sentido da ação humana é incapaz de diferenciar o trabalho e a vida pessoal, desconhece o público, apenas reifica o privado. A experiência social era de qualidade distinta daquela que incita e alça ações de organização política e de classe. Toda a liberação dava-se através de formas discretas e instáveis, no balanceio ambíguo de sujeitos e intenções, em que somente a vivência concreta de uma experiência deixava ver possíveis significados contraditórios e, alguma vez, sutilmente liberalizantes. A ambiguidade da situação colonial consiste em sintetizar em experiências concretas um espírito de autonomia subjetiva ao mesmo tempo em que as condições objetivas materializavam-se opressivas nos grilhões forjados. 0 escravo aprendeu talentosamente, numa poesia rara das formas sociais, a renegar com o espírito revolto no mesmo gesto em que a boca emitia o som da palavra que obedecia.

\section{Referências bibliográficas}

CAndido, A. (1970). "Dialética da malandragem”. Revista do Instituto de Estudos Brasileiros, São Paulo, n. 8.

CARdoso, F. H. (2003). Capitalismo e escravidão no Brasil meridional. O negro na sociedade escravocrata do Rio Grande do Sul. Rio de Janeiro, Civilização Brasileira.

Franco, M. S. C. (1974). Homens livres na ordem escravocrata. São Paulo, Ática.

SAfatle, V. (2010). Fetichismo. Colonizar o outro. Rio de Janeiro, Civilização Brasileira.

(2008). Cinismo e falência da crítica. São Paulo, Boitempo.

Schwarz, R. (2000). "As ideias fora do lugar". In: Ao vencedor as batatas. Forma literária e processo social nos inícios do romance brasileiro. São Paulo, Duas Cidades/ Editora 34.

(2000). "A importação do romance e suas contradições em Alencar". In: Ao vencedor as batatas. Forma literária e processo social nos inícios do romance brasileiro. São Paulo: Duas Cidades, Editora 34.

Simmel, G. (2009). "Psicologia do dinheiro". In: Psicologia do dinheiro e outros ensaios. Lisboa, Texto \& Grafia.

Weber, M. (1999). "Comunidade de vizinhança, comunidade econômica e comuna”. In: Economia e sociedade. Brasília, UnB; São Paulo, Imprensa Oficial do Estado de São 
Paulo, v. 1.

Williams, E. (1944). Capitalism and Slavery. North Carolina, The University of North Carolina Press. Disponível em: http://archive.org/details/capitalismandsla033027mbp. Acesso em: 17/11/2014.

Recebido em dezembro/2012

Aprovado em novembro/2014 